\title{
ANALYSIS OF SHIP WAITING TIME TO GET SHIPYARD SERVICE AT PT. DOKP AND SHIPPING WAIAME IN AMBON CITY
}

\author{
Husnyati Kiat ${ }^{1}$ \\ ${ }^{1}$ Universitas Darussalam Ambon, Jl. Waehakila Puncak Wara, Ambon \\ Email: husnyatikiatunidar@gmail.com
}

Article History
Received: 22-05-2020
Revision: 26-06-2020
Accepted: 04-09-2020
Published: 05-09-2020

\begin{abstract}
The purpose of this research is to determine the best service system that can be applied by PT. Dokp and Shipping Waiame Ambon. so that the waiting time can be pressed. This research is descriptive research, with the population in this study is the entire number and type of ships that have docked at PT. DOKP and Waiame shipping for 13 months. The sampling method used in this research is Convenience Sampling. The sample used in this study is the number of ships repaired in a period of up to 13 months. The analysis tool used is queueing theory of multi channel-single phase model. The results showed that the average arrival rate of ships per month is as many as 9 units of ships, while the average length of docking as much as 3 units of ships / month. Therefore, it can be seen that the level of service is not optimal to reduce the arrival rate of ships, and the chance of idleness by 2 . Therefore, the arrival of ships is more than the level of ship service at PT. Dokp and Shipping Waiame Ambon.
\end{abstract}

Keywords: Waiting Time, Service Level

\begin{abstract}
Abstrak. Tujuan penelitian ini adalah untuk menentukan sistem pelayanan yang terbaik yang dapat diterapkan oleh PT. DOKP dan Perkapalan Waiame Ambon. agar waktu tunggu dapat ditekan. Penelitian ini merupakan penelitian deskriptif, dengan populasi dalam penelitian ini adalah seluruh jumlah dan jenis kapal yang pernah docking di PT. DOKP dan perkapalan Waiame selama 13 bulan. Metode pengambilan sampel yang digunakan dalam penelitian ini adalah Convenience Sampling. Sampel yang digunakan dalam penelitian ini adalah jumlah kapal yang di perbaiki dalam kurun waktu sampai 13 bulan. Alat analisis yang digunakan adalah Analisis Teori Antrian (Queueing Theory) model multi channel-single phase. Hasil penelitian menunjukkan bahwa diperoleh rata-rata tingkat kedatangan kapal per bulan adalah sebanyak 9 unit kapal, sedangkan rata-rata lama dok sebanyak 3 unit kapal/bulan. Maka dari data ini, dapat dilihat bahwa tingkat pelayanan kurang optimal untuk menekan tingkat kedatangan kapal, dan peluang menganggur sebesar 2. Olehnya itu kedatangan kapal lebih banyak dari tingkat pelayanan kapal pada PT. Dokp dan Perkapalan Waiame Ambon.
\end{abstract}

Kata Kunci: Waktu Tunggu, Tingkat Pelayanan

How to Cite: Kiat, H. (2020). Analysis of ship Waiting Time to Get Shipyard Service at PT. DOKP and Shipping Waiame in Ambon City. Indo-Fintech Intellectuals: Journal of Economics and Business, 1 (1), 40-50. http://doi.org/10.54373/ifijeb.v1i1.15

\section{INTRODUCTION}

In the field of marine transportation, the maintenance of ships in the field of sea transportation is one of the most important activities because it can determine the feasibility 
of a ship. In addition, ship maintenance is one of the very complex and dynamic processes with interdependence between variables that are quite high, one of which is information. However, most of the information scattered in several stages of the process is generally incomplete and reliable. The level of accuracy of the estimated duration of ship maintenance affects the quality of shipyard service and becomes very important as a result of the shipyard's business process. If the maintenance duration is too long, then the shipyard will become unespective and if the duration becomes shorter, then the material supply schedule will fall apart and reduce the quality of workers' work performance due to unrealistic duration (Srdoc et al. 2006).

The shipyard is a place designed to build, maintain and repair ships. Currently there are about 240 domestic shipyard companies spread across Indonesia, 37\% on the island of Java, $26 \%$ on the island of Sumatra, $25 \%$ in Kalimantan and $12 \%$ in the eastern region of Indonesia, with a ship building capacity of 140,000 GT (Gross Tonnage) per year (Windyandari, 2008).

Queues, is a phenomenon that often occurs when the demand for a service at certain times exceeds the capacity of the service. In general the busy period can be described with the process of the queue system starting when the customer arrives, then waiting, and will end when the customer leaves the system. Throughout busy periods there is always at least one customer in the system (Ferreira, 2011:195). The occurrence of queues and human behavior becomes something that is inseparable from the problem of queues, this is one of the factors of uncertainty (randomize) and also very influential in the service system. One way that can be used to observe systems that contain uncertain factors is to use a single service queue system method and that will present a real system, with which it is possible to be able to observe how this method system behaves. The more capable the service system imitates the real system, the better the method.

PT. DOKP and Shipping Waiame Ambon, is one of the shipyards that has been established since 1965. $42 \%$ share ownership is owned by the Government of Maluku and $58 \%$ owned by the central government through PT. DOKP and Shipping Surabaya. Pt. DOKP and Waiame Ambon Shipping became central to ship repair and new shipbuilding in eastern Indonesia. Area of PT. DOKP and Shipping Waiame Ambon is 5 (five) Ha, Watter Front 720 $\mathrm{M}$, with a depth of 8-20 M, with shipyards can be seen in table 1 below. 
Table 1. Slip Way Facilities and Air Bag Dock Facility PT. DOKP and Shipping Waiame Ambon

\begin{tabular}{|c|c|c|c|}
\hline No & Dock & Shipyard Line & Capacity \\
\hline \multirow{2}{*}{\multicolumn{2}{|c|}{$1 \quad$ Slip Way }} & $\mathrm{I}$ & 200 TLC \\
\hline & & II & 500 TLC \\
\hline \multirow[t]{3}{*}{2} & Air Bag System & I (West) & 200 TLC \\
\hline & & II (Central) & 200 TLC \\
\hline & & III (East) & 500 TLC \\
\hline
\end{tabular}

Source: PT. DOKP And Shipping Waiame Ambon 2016

PT. DOKP and shipping waiame Ambon, can perform ship repair and maintenance such as: Ship engine overhaul, Propeller repair, anchor chain maintenance, welding, drilling, also painting and zinct-anado. There are 4 types of ship maintenance service system in PT. DOKP and Shipping Waiame Ambon. Where it is listed in table 2 below.

Table 2. Types of Ship Maintenance Service System at PT. Waiame Ambon Dock and Shipping

\begin{tabular}{ll}
\hline System I & Overhaul $\rightarrow$ propeller repair $\rightarrow$ anchor chain maintenance $\rightarrow$ welding \\
& $\rightarrow$ drilling $\rightarrow$ painting $\rightarrow$ zinct-anado
\end{tabular}

\begin{tabular}{ll}
\hline System II & Overhaul $\rightarrow$ propeller repair $\rightarrow$ painting \\
\hline System III & Overhaul $\rightarrow$ anchor chain maintenance \\
\hline System IV & Overhaul $\rightarrow$ welding $\rightarrow$ drilling $\rightarrow$ painting $\rightarrow$ zinct-anado.
\end{tabular}

Source : PT. DOKP And Waiame Ambon Shipping, 2016

During the period of 13 months there were 5 (five) units of ships that retreated from the queue. The cause is the ship's waiting time which exceeds 15-20 days. Then the ship's company may withdraw from the queue list or choose to move to another ok-dock. The impact of ships that disembark or retreat from the queue is PT. Dokp And Waiame Shipping refunds the costs paid by the ship company and with an additional $20 \%$ of the fee paid by the ship company. So in this case PT. Dokp and Waiame Ambon Shipping will suffer losses.

PT. DOKP and Shipping Waiame Ambon has a requirement for each ship docking, for each company that will do doking, namely (a) fill out the ship company form, (b) the weight of the ship must comply with the weight of the shipyard, (c) agree to the contract to pay a fine of $20 \%$ from the ship to PT. DOKP and Perkapalan Waiame if the ship declared disembarking from the galanagan suda in the process of work, (d) Agreed to a contract to pay a fine of $20 \%$ of PT. DOKP and Perkapalan Waiame Ambon to the ship if the party declared 
to withdraw from the queue list too long, and (e) After the process on board the new ship bias conducted checks.

\section{METHOD}

This research is descriptive research, which is research conducted to find out the value of independent variables, either one variable or more (independent) without making comparisons or connecting between variables with each other (sugiyono, 2011). The population in this study is the entire number and type of ships ever docked at PT. DOKP and Waiame shipping for 13 months. The sampling method used in this study is Convenience Sampling which is a convenient sampling conducted by choosing a free sample as desired by the researcher (Jogiyanto: 2009). The samples used in this study were the number of vessels repaired within a period of up to 13 months. Data collection techniques used in this study are observations, interviews, and documentation.

The analysis method used in this study is quantitative analysis method, where there are 3 (three) components in the queue system that will be measured, namely: 1) arrival, population to be served (calling population); 2) queue; and 3) service facilities. The analysis tool used is queue by using multi channel-single phase method. Multi channel-single phase is a method that occurs (there) anytime two or more service facilities are watered by a single queue, to find out can be seen in the following scheme.

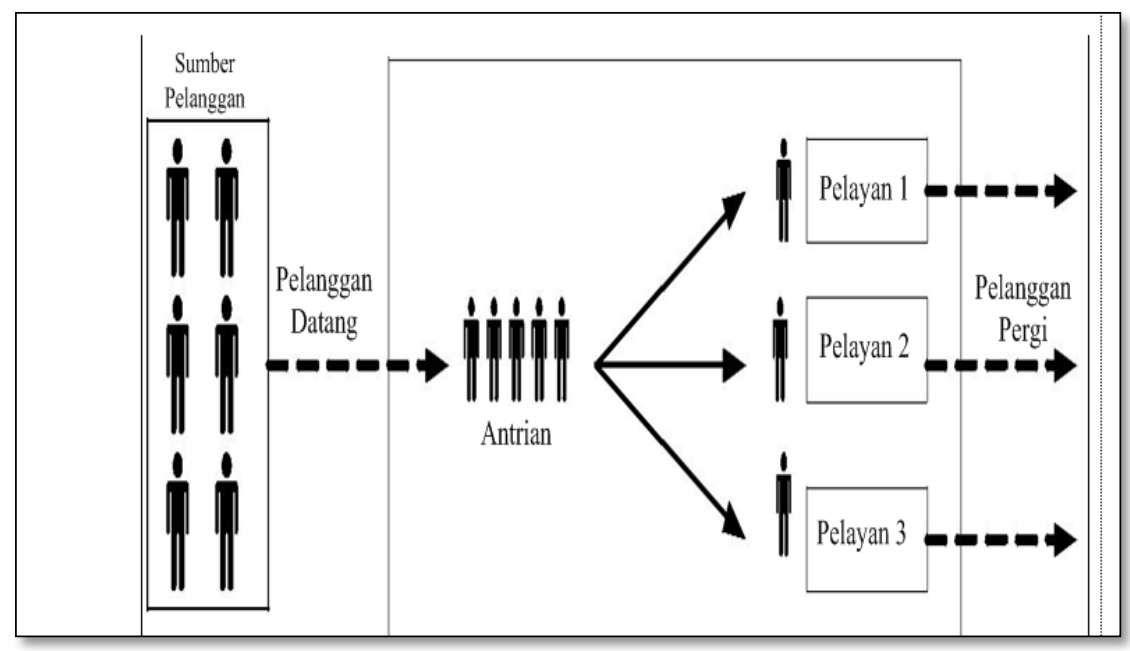

The queue formula for the $\mathrm{M} / \mathrm{M} / \mathrm{s}$ model is as follows.

Average number in queue $(L q)$

$$
L q=\frac{\lambda^{2}}{\mu(\lambda-\mu)}
$$


Average number in the system $(L s)$

$L s=\frac{\lambda}{\lambda-\mu}$

Average time in queue $(W q)$

$W q=\frac{\lambda}{\mu(\lambda-\mu)}$

Average time in the system $(W s)$

$W S=\frac{1}{\lambda-\mu}$

Probability there are 0 customers in the system $(P 0)$

$P 0=1-\frac{\lambda}{\mu}$

Service level of The Shipyard Line $(P)$

$P \quad=\frac{\lambda}{\mu}$

\section{RESULTS}

\section{Queue System Model PT. DOKP And Shipping Waiame Ambon}

Type of queue system used by PT. DOKP and Waiame Shipping in Ambon City is a multi-channel single phase queue system, where there are 2 (two) shipyards namely Slip Way Shipyard (Line I and Line II) and Air Bag System Shipyard (West, Central and East Line) provided to serve each ship unit, but only one phase is passed to transact through the treasurer of PT. Dokp and Waiame Shipping. In general, the process of stages in the dosing as follows.

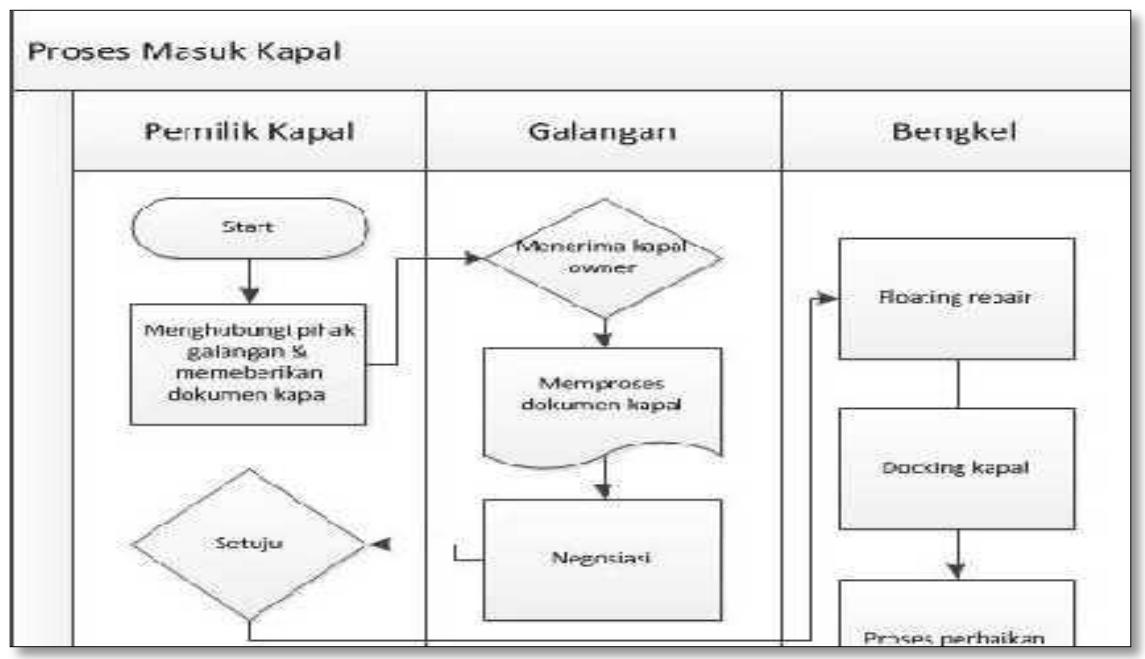

Figure 2. Cross Functional Flowchart Ship Entry Process 


\section{Shipbuilding Process}

The work when the ship enters the shipyard or the repair process are:

Table 2. Ship Maintenance Service System at PT. Waiame Ambon Dock and Shipping

\begin{tabular}{|c|c|c|}
\hline No & Maintenance & Explanation \\
\hline 1 & Overhaul & $\begin{array}{l}\text { Overhaul is the first stage of maintenance and repair for } \\
\text { cleaning, measurement, analysis, replacement of new tools } \\
\text { on the material parts of the machine that have been } \\
\text { damaged. }\end{array}$ \\
\hline 2 & $\begin{array}{l}\text { Propeller Repair } \\
\text { (Propeller Repair) }\end{array}$ & $\begin{array}{l}\text { Repair by removing the propeller and cleaned, then repair } \\
\text { dun propeller if there is damaged or bent. }\end{array}$ \\
\hline 3 & $\begin{array}{l}\text { Anchor chain } \\
\text { maintenance }\end{array}$ & $\begin{array}{l}\text { Anchor care on the anchor rod (Shank), Nail anchor hook } \\
\text { (throat) and anchor chain by cleaning the rust and salt of sea } \\
\text { water and cleaning between the anchor rope holes with a } \\
\text { brush and special oil. }\end{array}$ \\
\hline 4 & Welding & $\begin{array}{l}\text { Repair of the ship starting from inside the ship part is the } \\
\text { construction profile or skeleton of the ship, then following } \\
\text { the leather part of the ship and hull in the form of plates. }\end{array}$ \\
\hline 5 & Drilling & $\begin{array}{l}\text { Maintenance of the vessel by drilling the hull plate that has } \\
\text { been thinned or perforated due to rust or collision and } \\
\text { replacing the plate with the same thickness as the part that is } \\
\text { not drilled. }\end{array}$ \\
\hline
\end{tabular}

6 Painting The painting process is done after the ship in blasting, the use of paint for ships on PT. Waiame Ambon dock and shipping are basic paint, AC paint (anti-rust paint), AF paint (anti-marine animal paint, mushrooms and marine plants

\begin{tabular}{ll}
\hline 7 zinct - anado. & A mixture of Tin, aluminum, magnesium, which is used to \\
& protect the iron against corroation or rust attached to the hull \\
& and attached to the ship's plate.
\end{tabular}

Source : PT. DOKP and Ship Waiame Ambon 2016

\section{Queue System Performance PT. DOKP and Waiame Ambon Shipping}

Data acquisition of ship waiting time and docking length by directly observing the number of ships entering the shipyard line Air Bag System Central Line and East Line PT. DOKP and Waiame Ambon Shipping. The results of observation of the level of arrival of ships at PT. DOKP and Waiame Ambon Shipping can be seen in the following table. 
Table 3. Observation Of Waiting Time And Ship Dock Time At PT. Dokp And Waiame Ambon Shipping In January 2016 - February 2017

\begin{tabular}{|c|c|c|c|c|c|c|}
\hline \multirow[b]{2}{*}{$\begin{array}{l}\text { Shipyard } \\
\text { Line }\end{array}$} & \multirow[b]{2}{*}{ Ship Name } & \multirow[b]{2}{*}{$\begin{array}{c}\text { Arrival } \\
\text { Time }\end{array}$} & \multirow{2}{*}{$\begin{array}{c}\text { Long } \\
\text { Wait } \\
\text { (days) }\end{array}$} & \multicolumn{2}{|c|}{ Docking Time } & \multirow{2}{*}{$\begin{array}{l}\text { Long } \\
\text { Dock } \\
\text { Time } \\
\text { (Day) }\end{array}$} \\
\hline & & & & Dock ride & $\begin{array}{c}\text { Get off the } \\
\text { dock }\end{array}$ & \\
\hline \multirow{5}{*}{$\begin{array}{c}\text { Air Bag } \\
\text { System } \\
\text { Central } \\
\text { Line }\end{array}$} & TK. LPN -03 & 09-01-2016 & 10 & 19-01-2016 & 03-05-2016 & 104 \\
\hline & $\begin{array}{l}\text { MT. BERKAT } \\
\text { ANUGERAH - } 02\end{array}$ & $29-05-2016$ & 7 & 04-06-2016 & $17-08-2016$ & 74 \\
\hline & $\begin{array}{l}\text { MT. BERKAT } \\
\text { ANUGERAH - } 03\end{array}$ & $12-08-2016$ & 6 & $18-08-2016$ & 24-09-2016 & 35 \\
\hline & KMP. LAYUR & $20-09-2016$ & 2 & $22-10-2016$ & $18-11-2016$ & 27 \\
\hline & TK. CAPRICORN - 15 & $30-11-2016$ & & $30-11-2016$ & 09-02-2017 & 71 \\
\hline \multirow{13}{*}{$\begin{array}{c}\text { East Line } \\
\text { Air Bag } \\
\text { System }\end{array}$} & KMP. TEMI & $10-02-2016$ & & $10-02-2016$ & $23-02-2016$ & 15 \\
\hline & KMP. WAYANGAN & $15-03-2016$ & & $15-03-2016$ & 24-03-2016 & 25 \\
\hline & KMP. INILAKA & $20-04-2016$ & 7 & $27-04-2016$ & $22-05-2016$ & 8 \\
\hline & KMP. TATIHU & $20-07-2016$ & & $20-07-2016$ & 08-08-2016 & 30 \\
\hline & KMP. ROKATENDA & $05-08-2016$ & 6 & $11-08-2016$ & 03-09-2016 & 11 \\
\hline & KMP. LOBSTER & 09-09-2016 & & 09-09-2016 & $02-10-2016$ & 17 \\
\hline & KMP. BADA LEONI & 29-09-2016 & 7 & 06-10-2016 & $17-10-2016$ & 73 \\
\hline & KMP. ERANA & $20-10-2016$ & & $20-10-2016$ & $01-11-2016$ & 20 \\
\hline & $\begin{array}{l}\text { KMP. TANJUNG } \\
\text { KABAT }\end{array}$ & 04-11-2016 & & 04-11-2016 & $17-11-2016$ & 9 \\
\hline & KMP. TANJUNG SOLE & 09-11-2016 & 9 & $18-11-2016$ & $29-11-2016$ & 30 \\
\hline & KMP. DANAU RANA & $20-11-2016$ & 9 & $29-11-2016$ & $20-12-2016$ & 14 \\
\hline & Amount & & 63 & & & 563 \\
\hline & Average & & 7 & & & 9 \\
\hline
\end{tabular}

Source : Observation Results in 2017

The longest waiting time for shipyard service is at the Central Line Air Bag System Shipyard for 10 days, namely on 09-01-2016 with a dock time of 104 days, namely on 19-012016 until 03-05-2 016 and the fastest time tuggu shipyard service for 2 days that is on 2009-2016 with a length of dock time for 27 days that is on 22-10-2016 to 18-11-2016.

Tabel 4. Average Length of Time Dock Ship On Shipyard Air Bag System Middle Line And East Line

\begin{tabular}{cccc}
\hline Jalur Galangan Kapal & $\begin{array}{c}\text { Total Lama } \\
\text { Dock }\end{array}$ & $\begin{array}{c}\text { Lama } \\
\text { Tunggu }\end{array}$ & Rata-Rata Lama Dok \\
\hline Air Bag System Jalur Tengah & 311 & 25 & 12.44 \\
\hline Air Bag System Jalur Timur & 252 & 38 & 6.63 \\
\hline
\end{tabular}

Sumber : Hasil Pengamatan (data diolah) Tahun 2017 


\section{Queue Process}

On this model the distributed arrival of poisson and exponential service time. In this situation, the arrival forms a single line to be served by a single station. It is assumed that the system is in the following conditions.

1. Arrivals are served on the basis of First Come First Serve (FCFS) and each arrival waits to be served, regardless of the length of the queue.

2. Arrivals are not tied to previous arrivals, it's just that the average number of arrivals does not change by time.

3. Arrival is illustrated by poisson probability distribution and comes from an infinite (very large) population.

4. Service time varies from one ship to the next and is not tied to each other, but the average level of service is known.

5. Service time corresponds to the distribution of negative exponential probability.

6. The level of service cannot keep up with the level of ship arrival.

\section{M/M/s Queue Model Analysis Results}

According to Heizer and Render (2009), some common queue models one of which is Multi Chanel Single Phase that occurs if there are two or more service facilities are flowed by a single queue, just like the model of shipyard service line Air Bag System Middle and East Line at PT. Dokp and Perkapalan Waiame Ambon which has 2 capacities (200 TLC and 500 TLC) with one-stage service.

Table 5. Performance Results of Model M/M/s Queue System on PT. DOKP And Shipping Waiame Ambon

\begin{tabular}{ccccccc}
\hline \multirow{2}{*}{$\mathbf{1}$ Month Time Period } & \multicolumn{6}{c}{ Queue System Performance } \\
\cline { 2 - 7 } & $\boldsymbol{L q}$ & $\boldsymbol{L}$ & $\boldsymbol{W q}$ & $\boldsymbol{W s}$ & $\boldsymbol{P}_{\boldsymbol{0}}$ & $\boldsymbol{P}$ \\
\hline 30 days & 4,5 & 1,5 & 180 & 0,17 & 2 & 3
\end{tabular}

Source : Observations of data processing in 2017

Based on the calculation of table 5 above, within a period of 30 days ( 1 month) it can be explained that:

1. The average number of ships in the queue (Lq) is 4.5 units / month.

2. The average number of ships in the system that are being served at the shipyard (Ls) is 1.5 units / month. 
3. The average waiting time of the ship in the queue (Wq) is 180 days.

4. The average waiting time of a ship in the system (Ws) was 0.17 months (141 days).

5. Probability of 0 units of ships in the system or the level of possibility of idle service (P0) is $2 \%$.

6. The service level of The Shipyard Line (P) is $3 \%$ per month.

\section{DISCUSSION}

The results of the study conducted by the author at PT. Dokp And Shipping Waiame Ambon is to determine the best service system that can be applied by PT. Dokp and Shipping Waiame Ambon so that the waiting time can be reduced. Pt.. Dokp And Shipping Waiame Ambon has 2 capacities on 2 Line Shipyard Air Bag System namely 200 TLC for The Middle Line and 500 TLC for the East Line, it shows that the channel used is double (Multi Channel).

The structure of the queue model that occurs in PT. Dokp And Shipping Waiame Ambon is a Multi Channel Single Phase. By implementing the First Come First Serve (FCFS) system, which is where the ship comes first will be served first. During the period of 13 months there were 5 (five) units of ships that retreated from the queue. Which is where the cause is the waiting time of the ship that exceeds from 15-20 days. Then the ship's company could have backed out of the queue list or chosen to move to another ok-dock. The impact of ships that disembark or retreat from the queue is PT. Dokp And Waiame Shipping refunds the costs paid (panjar) by the ship company and with an additional $20 \%$ of the fee paid by the ship company. So in this case PT. DOKP And Shipping Waiame Ambon will suffer losses.

PT.DOKP And Waiame Shipping serve ships for 6 working days a week, and 9 hours of work on a daily basis. At the time of service starting from the observation time there is that the longest shipyard service waiting time is at the Central Line Air Bag System Shipyard with a waiting time of 10 days with a dock time of 104 days, while the waiting time of the shipyard service is the fastest for 2 days with a dock time of 27 days. The results showed that the average rate of ship arrival per month is as much as 9 units of ships, while the average docking time is 3 units of ships / month. Therefore, from this data, it can be seen that the level of service is less optimal to reduce the level of ship arrival, and the chance of idleness by 2. Therefore the arrival of ships is more than the level of service of ships at PT. DOKP and Waiame Ambon Shipping.

Rambat Lupiyoadi (2006) suggests that services are all economic activities whose results are not products in physical or construction form, which are usually consumed at the same 
time as the resulting time and provide added value (such as convenience, entertainment, pleasure or health) or solutions to problems faced by consumers. Meanwhile, according to Stevenson (2009) explained that the management of the system or process that creates goods and / or provides services. And Herjanto (2003) Operations management is inseparable from the understanding of management in general, which contains elements of activities carried out by coordinating as activities and resources to achieve a certain goal.

\section{CONCLUSION}

Based on the results of the research that has been done following submitted the conclusion that PT. Dokp And Shipping Waiame Ambon has 2 capacities on 2 Line Shipyard Air Bag System namely 200 TLC for The Middle Line and 500 TLC for the East Line, it shows that the channel used is double (Multi Channel). While the transaction process on the treasurer PT. DOKP And Shipping Waiame Ambon shows there is only one stage (Single Phase). So, the structure of the queue model that occurs in PT. DOKP and Shipping Waiame Ambon is a Multi Channel Single Phase. By Implementing a First Come First Serve (FCFS) system. Pt.. DOKP and Waiame Shipping serve customers for 6 working days a week, and 9 working hours on a daily basis. The service time starts from 08.00-17.00 WIT. During the observation time there is that the longest waiting time of the shipyard service is at the Central Line Air Bag System Shipyard for 10 days, while the fastest shipyard service tuggu time for 2 days is. the average rate of ship arrival per unit time is as much as 9 units of ships, while the average dock length is 3 units of ships. Means the average arrival rate is greater than the service level

\section{REFERENCES}

A.K.Erlang. 2011. "Sejarah Teory Antrian" dalam modul manajemen operasional. Jakarta Ariani D. Wahyu, 2009. Manajemen Operasi Jasa. Edisi Pertama : Yogyakarta

Ferreira, D. 2011. Women in the Boardroom and Their Impact on Governance and Performance. Journal of Financial Economics, 94(2) 291-309

Hadi yamin. (2014). Optimasi Waktu Untuk Layout Galangan Kapal PT. Dokp Dan Perkapalan Waiame Ambon: Universitas Patimura ambon.

Mustafa S, Kurniawaty E. 2013. Manajemen gangguan saluran cerna panduan bagi dokter umum. Lampung: Anugrah Utama Raharja(Aura).

Petrus Rose Cahyomagri, 2008. Aplikasi Model Antrian sebagai Upaya Optimalisasi Kinerja Pelayanan pada Jasa Perbankan (Studi Pada PT. Bank Muamalat Indonesia Tbk. Kantor Cabang Malang).(Skripsi),

Reichelt, Ken dan Francis, Jere R. 2002. The Effect of Fee Dependence on Non Big 5 Clients' Accruals. 
Satriawan andhik 2012. Studi Peningkatan Pendayagunaan Sarana Pengedokan Kapal Di Pt Dok \& Perkapalan Surabaya. Jakarta : Erlangga

Siagian, P., 1987, Penelitian Operasional : Teori dan Praktek, Universitas Indonesia Press. Jakarta

Suad Husnan, 2015. Teori Antrian dan Penggunaanya bagi Manajemen, Yogyakarta: BPFE UGM.

Subagyo, P., dkk, 2000, 'Sejarah Teori Antrian', in A.K. Erlang (ed.), Dasar -dasar Operations Research, BPFE. Yogyakarta

Sugiono (2011). Metode penelitian kuantitatif kualitatif dan R \& D. alfabeta

Sugiyono, 2013. Metodologi Penelitian Bisnis, Alfabeta, Bandung

Tawainella, Abduh, 2010.Skripsi : Pengaruh Kualitas Pelayanan terhadap Kepuasan Pasien pada RSUD Tulehu,Universitas Darussalam Ambon.

Transtrianingzah, Fia, 2006. Analisis Pengaruh Kualitas Pelayanan terhadapTingkat Kepuasan Nasabah pada Bank Muamalat Cabang Solo (Skripsi), Surakarta : STAIN.

Wawan yoga 2011. Penerapan Sistem Mrp Pada Pembangunan Kapal. Yogyakarta: Nuha Medika

Windyandari, A. 2008. Prospek Industri Galangan Kapal Dalam Negeri Guna Menghadapi Persaingan Global. Jurnal TEKNIK. Vol. 29 No. 1: 73 